\title{
Family Relations and Spiritual Response to Palliative Care: a Review of Literature
}

Pedro Alberto Martins Freire Filho', Séfora Batista Almeida1, Débora Batista Almeida Siebra², lanny Alcântara Martins Lavor ${ }^{3}$, Albério Ambrósio Cavalcante ${ }^{4}$, Ana Carolina Lustosa Saraiva ${ }^{5}$, Ivo Saturno Bonfim², Michele Ferreira Moreira5, Raquel de Menezes Sobreira6, Diego Jorge Souza Ezequiel ${ }^{5}$, Séfora dos Santos Feitosa7, Erich Pires Lisboa ${ }^{8}$

\section{Abstract}

Introduction: It is common to prioritize the critical patient care in detrainment of the caregivers, but this usual behavior must change, maintaining the family members as an extension of the care given to patients.

Results and Discussion: Spiritual wellbeing is a complement to all health strands united with physical and psychosocial status, they must be put into the routine of practicing medicine on end of life care in congruence with a good communication.

Conclusion: At all levels of assistance in palliative care the family must be included, therefore clinicians shall have information on how to deal with them and developing activities to improve communication.

Palliative Care; Family Relations; Spirituality; Adult.

\section{Introduction}

Living with terminal illness implicates, most of the time, in dealing with existential questions, it is a state that involves the patient needs, family embrace and the health professional worries. It is common and even considered normal, to prioritize the critical patient care in detrainment of the caregivers, but there is a need to change this usual behavior and maintain the family members as an extension of the care. 
Palliative care is "an approach that improves the quality of life of patients and their families facing the problem associated with life-threatening illness, through the prevention and relief of suffering by means of early identification and impeccable assessment and treatment of pain and other problems, physical, psychosocial and spiritual" by the definition of the World Health Organization (WHO, 2002) [1]. Palliative care is not just at the end of life, it must be provided anytime during a life-threatening illness [2]. It is needed to have a holistic view of the person, focusing on pain and management of symptoms as well as emotional, spiritual and social well-being, their loved ones included in it.

Spiritual caregiving meets the need of the majority of those patients. Spirituality is one of the main aspects of end of life care [3], it is necessary to put spiritual guidance into the routine of practicing medicine at special care units, intensive care units, hospices and every care of patients who integrates the group of incurable illnesses.

There are few studies reflecting the family relations and spiritual response to palliative care, our review intends to expose the family questions and needs while facing this intriguing time and how spirituality reflects on it.

\section{Methods}

Focusing on Palliative Care, a qualitative systematic review of articles about family relations and spiritual response to palliative care in hospitalized adults was realized on a basis of preselected data. A search of the literature was performed from the online database SCOPUS, BVS and PUBMED from January, 2006 to December, 2015. The search was focused from the following terms: 1. 'Palliative Care' \{Medical Subject Headings\} [MeSH term], 2. 'Spirituality' \{Medical Subject Headings\} [MeSH term], 3. 'Family Relations' \{Medical Subject Headings\} [MeSH term] and 3. 'Adults' \{Medical Subject Headings\} [MeSH term].
The choice of these terms was made from a cautious conciliation, which applied to define our central matter of the article based on requested descriptors. Thus, the articles were analyzed with rigor to guarantee proper sampling.

The analysis of the articles obeyed predefined eligibility criteria. Using the following inclusion criteria: (1) Original articles with full text online access; (2) Observational, experimental or quasi-experimental studies; (3) Writings in English only; and (4) Studies which focus family relations and spiritual response to palliative care in hospitalized adults.

Exclusion criteria: (1) Other projects, such as case reports, case series, literature review and comments, (2) The non-original studies, including editorials, comments, prefaces, brief comments and letter to the editor; (3) Productions that did not address depression and the hospitalized old patients; and (4) the articles in which the objective of the study did not matched the theme purposed by the systematic review in question.

We found applicable 41 articles that, when screened, resulted in 14 articles that met the criteria of evidence and were included in this review.

\section{Results}

\section{Results in Table 1.}

\section{Discussion}

Palliative care is to improve the "quality of life of patients and their families facing the problem associated with life-threatening illness" (WHO, 2002) [1] the means to it is to have an early identification, treating and preventing pain and to support on other problems such as physical, spiritual or social. It is a specialty that requires great commitment from the health care workers, the caregivers and families, not just by the delicacy of the patient's condition but also because of the existential and spiritual distress involved [3]. 
Table 1. Distribution of the domains and facets of QoL. João Pessoa, PB, 2015.

\begin{tabular}{|c|c|c|c|c|c|c|c|}
\hline $\mathbf{N}$ & $\begin{array}{l}\text { Authors } \\
\text { and } \\
\text { Year }\end{array}$ & Title & Journal & Sample & Main findings & Conclusion & Database \\
\hline 1 & $\begin{array}{l}\text { Monica } \\
\text { Schneider, } \\
\text { Rose Steele, } \\
\text { Susan } \\
\text { Cadell, } \\
\text { David } \\
\text { Hemsworth } \\
2011\end{array}$ & $\begin{array}{l}\text { Differences on } \\
\text { Psychosocial } \\
\text { Outcomes } \\
\text { Between Male } \\
\text { and Female } \\
\text { Caregivers of } \\
\text { Children With } \\
\text { Life-Limiting } \\
\text { Illnesses }\end{array}$ & $\begin{array}{l}\text { Journal of } \\
\text { Pediatric } \\
\text { Nursing }\end{array}$ & $\begin{array}{l}273 \text { parents } \\
\text { caring for children } \\
\text { with life-limiting } \\
\text { illnesses }\end{array}$ & $\begin{array}{l}\text { Findings suggest that significant gender } \\
\text { differences exist. }\end{array}$ & $\begin{array}{l}\text { Women reported higher average } \\
\text { scores compared with men for } \\
\text { meaning in caregiving, depression, } \\
\text { burden, and posttraumatic growth } \\
\text { and lower average scores for op- } \\
\text { timism. Correlations also revealed } \\
\text { some significant differences. Health } \\
\text { care professionals need to be aware } \\
\text { of gender differences and tailor their } \\
\text { interventions appropriately. }\end{array}$ & BVS \\
\hline 2 & $\begin{array}{l}\text { Timothy P. } \\
\text { Daaleman, } \\
\text { Barbara } \\
\text { M. Usher, } \\
\text { Sharon W. } \\
\text { Williams, } \\
\text { Jim } \\
\text { Rawlings, } \\
\text { Laura C. } \\
\text { Hanson, } \\
2008\end{array}$ & $\begin{array}{l}\text { An } \\
\text { Exploratory } \\
\text { Study of } \\
\text { Spiritual Care } \\
\text { at the End of } \\
\text { Life }\end{array}$ & $\begin{array}{l}\text { Annals } \\
\text { of Family } \\
\text { Medicine }\end{array}$ & $\begin{array}{l}\text { Our study } \\
\text { was based } \\
\text { on qualitative } \\
\text { research using } \\
\text { key informant } \\
\text { interviews and } \\
\text { editing analysis } \\
\text { with } 12 \text { clinicians } \\
\text { and other health } \\
\text { care workers } \\
\text { nominated as } \\
\text { spiritual caregivers } \\
\text { by dying patients } \\
\text { and their family } \\
\text { members. }\end{array}$ & $\begin{array}{l}\text { Being present was a predominant theme, mar- } \\
\text { ked by physical proximity and intentionality, or } \\
\text { the deliberate ideation and purposeful action } \\
\text { of providing care that went beyond medical } \\
\text { treatment. Opening eyes was the process by } \\
\text { which caregivers became aware of their patient's } \\
\text { life course and the individualized experience of } \\
\text { their patient's current illness. Participants also } \\
\text { described another course of action, which we } \\
\text { termed cocreating, that was a mutual and fl uid } \\
\text { activity between patients, family members, and } \\
\text { caregivers. Cocreating began with an affi rma- } \\
\text { tion of the patient's life experience and led to } \\
\text { the generation of a wholistic care plan that focu- } \\
\text { sed on maintaining the patient's humanity and } \\
\text { dignity. Time was both a facilitator and inhibitor } \\
\text { of effective spiritual care. }\end{array}$ & $\begin{array}{l}\text { Clinicians and other health care } \\
\text { workers consider spiritual care at } \\
\text { the end of life as a series of highly } \\
\text { fl uid interpersonal processes in } \\
\text { the context of mutually recognized } \\
\text { human values and experiences, } \\
\text { rather than a set of prescribed and } \\
\text { proscribed roles. }\end{array}$ & $\begin{array}{c}\text { BVS/ } \\
\text { SCOPUS }\end{array}$ \\
\hline
\end{tabular}




\begin{tabular}{|c|c|c|c|c|}
\hline $\mathbf{N}$ & $\begin{array}{c}\text { Authors } \\
\text { and } \\
\text { Year }\end{array}$ & Title & Journal & Sample \\
\hline 3 & $\begin{array}{l}\text { Kristin } \\
\text { Bingen, } \\
\text { Mary Jo } \\
\text { Kupst } \\
\text { and Bruce } \\
\text { Himelstein, } \\
2011\end{array}$ & $\begin{array}{l}\text { Development } \\
\text { of the } \\
\text { Palliative } \\
\text { Care Parental } \\
\text { Self-Efficacy } \\
\text { Measure }\end{array}$ & $\begin{array}{l}\text { Journal } \\
\text { of } \\
\text { Palliative } \\
\text { Medicine }\end{array}$ & $\begin{array}{l}\text { a list of questions were generated that asked parents } \\
\text { their level of confidence in carrying out tasks involved in } \\
\text { caring for a child with a potentially fatal medical condi- } \\
\text { tion in } 6 \text { palliative care domains: 1) medical discussion/ } \\
\text { decisions; 2) symptom management/medication; 3) daily } \\
\text { activities; 4) feelings/concerns; 5) spirituality; and 6) end- } \\
\text { of-life care. The PCPEM was narrowed to } 58 \text { questions } \\
\text { after expert reviews. Then, } 16 \text { caregivers of children re- } \\
\text { ceiving palliative care services and } 9 \text { bereaved caregivers } \\
\text { participated in individual focus interviews conducted by } \\
\text { a psychologist to obtain feedback about the content and } \\
\text { clarity of the PCPEM. }\end{array}$ \\
\hline
\end{tabular}

4 Elizabeth A Qualitative L. Ciemins, Analysis Jeannine of Patient Brant, and Family Diane Perspectives Kersten, of Palliative Elizabeth Care Mullette, and Dustin Dickerson 2015 of palliative reviewed using grounded theory methodology and medicine preliminary interpretations. A combined deductive and inductive iterative qualitative approach was used to identify recurring themes. The study was conducted in a physician-led, not-for-profit, multispecialty integrated health system serving three large, western, rural states. A purposive sample of 14 individuals who received palliative care services were interviewed alone or with their families for a total of 12 interviews.

\section{Main findings}

Results indicated that 53 of

the 58 questions were rated as "comfortable being asked," and 55 of the 58 questions were rated as "important" by the majority (>80\%) of the 25 caregivers.

Presence, Reassurance, and Honoring Choices emerged as central themes linked to satisfaction with palliative care services. Themes were defined as including health care professional attributes of respect, approachability, genuineness, empathy, connectedness, com- families, health care passion, sensitivity, an ability to providers must be listen, good communication, compassionate and provision of information, empowerment, and timeliness. Honoring Choices included those pertaining to treatment, spirituality, and family needs.
This suggests that it is feasible and valuable to ask caregivers difficult questions related to end-of-life care if done in a supportive and sensitive manner. Pilot testing of the PCPEM will be conducted to determine preliminary psychometric properties.

At end of life or during times of serious illness, patients and families identified behaviors of Presence, Reassurance, and Honoring Choices as important. empathetic and possess skills in listening, connecting, and interacting with patients and families. 


\begin{tabular}{|c|c|c|c|c|c|c|c|}
\hline $\mathbf{N}$ & $\begin{array}{c}\text { Authors } \\
\text { and } \\
\text { Year }\end{array}$ & Title & Journal & Sample & Main findings & Conclusion & Database \\
\hline 5 & $\begin{array}{l}\text { E Michiels, R } \\
\text { Deschepper, } \\
\text { J Bilsen, } \\
\text { Fmortier, } \\
\text { L Deliens, } \\
2009\end{array}$ & $\begin{array}{l}\text { Information } \\
\text { disclosure to } \\
\text { terminally ill } \\
\text { patients and } \\
\text { their relatives: } \\
\text { self-reported } \\
\text { practice of } \\
\text { Belgian clinical } \\
\text { specialists } \\
\text { and general } \\
\text { practitioners }\end{array}$ & $\begin{array}{l}\text { Palliative } \\
\text { Medicine }\end{array}$ & $\begin{array}{l}\text { A questionnaire had been } \\
\text { sent to a random sample } \\
\text { of } 3014 \text { Belgian physicians } \\
\text { from different specialties } \\
\text { frequently involved in end- } \\
\text { of-life care. Responses were } \\
\text { analysed using weighted } \\
\text { percentages, Chi-square, } \\
\text { Mann-Whitney U-tests and } \\
\text { a multivariate ordinal logistic } \\
\text { regression. }\end{array}$ & $\begin{array}{l}\text { Response rate was } 58 \% \text {. Both clinical } \\
\text { specialists and general practitioners } \\
\text { (GPs) discuss most topics related to } \\
\text { terminal illness with their patients } \\
\text { except end-of-life hastening options, } \\
\text { spirituality, life expectancy and } \\
\text { options to withhold/withdraw life- } \\
\text { sustaining treatment. }\end{array}$ & $\begin{array}{l}\text { The topics which most physicians } \\
\text { always discuss with relatives without } \\
\text { informing the patient are the aim } \\
\text { of treatment, palliative care and } \\
\text { incurability. There is a significant } \\
\text { difference between clinical specialists } \\
\text { and GPs. Clinical specialists and GPs } \\
\text { discuss most end-of-life topics with } \\
\text { the patient but omit important issues } \\
\text { such as end-of-life hastening options } \\
\text { and lifeexpectancy. }\end{array}$ & $\begin{array}{c}\text { BVS/ } \\
\text { SCOPUS }\end{array}$ \\
\hline 6 & $\begin{array}{l}\text { Carmen } \\
\text { G Loiselle, } \\
\text { Michelle } \\
\text { M Sterling } \\
2011\end{array}$ & $\begin{array}{l}\text { Views on } \\
\text { death and } \\
\text { dying among } \\
\text { health care } \\
\text { workers in an } \\
\text { Indian cancer } \\
\text { care hospice: } \\
\text { Balancing } \\
\text { individual } \\
\text { and collective } \\
\text { perspectives }\end{array}$ & $\begin{array}{l}\text { Palliative } \\
\text { Medicine }\end{array}$ & $\begin{array}{l}\text { This qualitative study } \\
\text { explores and compares } \\
\text { these experiences among } \\
\text { a diverse sample of health } \\
\text { workers (N1/425) in a } \\
\text { grassroots cancer care } \\
\text { hospice in Bangalore, India. } \\
\text { Our findings underscore } \\
\text { how personal views, socio- } \\
\text { economic status, beliefs } \\
\text { and values, occupational } \\
\text { experience, and workplace } \\
\text { interventions interact to } \\
\text { shape 'worldviews' about } \\
\text { death and dying. }\end{array}$ & $\begin{array}{l}\text { Whereas health workers report } \\
\text { conflicting feelings of relief and } \\
\text { sadness when confronted with } \\
\text { the death of their patients, these } \\
\text { mixed emotions are often lessened } \\
\text { through open dialogue among newly } \\
\text { trained and more experienced health } \\
\text { workers. Moreover, experienced } \\
\text { hospice workers wished to ensure } \\
\text { that less experienced ones are } \\
\text { provided with the necessary } \\
\text { workplace support to lessen } \\
\text { psychological 'hardening' that may } \\
\text { occur with repeated exposure to } \\
\text { death. }\end{array}$ & $\begin{array}{l}\text { In dealing with the diverse needs of } \\
\text { hospice workers, both individual and } \\
\text { collective needs must be considered } \\
\text { to ensure an optimal workplace } \\
\text { climate. Future work should study } \\
\text { how hospice workers' views on } \\
\text { death and dying evolve with time } \\
\text { and experience. }\end{array}$ & $\begin{array}{c}\text { BVS/ } \\
\text { SCOPUS }\end{array}$ \\
\hline
\end{tabular}




\begin{tabular}{|c|c|c|c|c|c|c|c|}
\hline $\mathbf{N}$ & $\begin{array}{c}\text { Authors } \\
\text { and } \\
\text { Year }\end{array}$ & Title & Journal & Sample & Main findings & Conclusion & Database \\
\hline 7 & $\begin{array}{l}\text { Brian Kelly, } \\
\text { Francis T } \\
\text { Varghese, } \\
\text { Paul Burnett, } \\
\text { Jane Turner, } \\
\text { Marguerite } \\
\text { Robertson, } \\
\text { Patricia Kelly, } \\
\text { Geoffrey } \\
\text { Mitchell, } \\
\text { Pat Treston, } \\
2008\end{array}$ & $\begin{array}{l}\text { General } \\
\text { practitioners' } \\
\text { experiences } \\
\text { of the psy- } \\
\text { chological } \\
\text { aspects in } \\
\text { the care of a } \\
\text { dying patient }\end{array}$ & $\begin{array}{l}\text { Palliative } \\
\text { and } \\
\text { Supportive } \\
\text { Care }\end{array}$ & $\begin{array}{l}\text { Fifteen general practitioners whose patient had } \\
\text { been recently referred to the Mt. Olivet Palliative } \\
\text { Home Care Services in Brisbane participated in } \\
\text { an individual case review discussions guided by } \\
\text { key questions within a semistructured format. } \\
\text { These interviews focused on the psychosocial } \\
\text { aspects of care and management of the referred } \\
\text { patient, including aspects of the doctor/patient } \\
\text { relationship, experience of delivering diagnosis and } \\
\text { prognosis, addressing the psychological concerns } \\
\text { of the patients' family, and the doctors' personal } \\
\text { experiences, reactions, and responses. Qualitative } \\
\text { analysis was conducted on the transcripts of these } \\
\text { interviews. }\end{array}$ & $\begin{array}{l}\text { The significant themes } \\
\text { that emerged related } \\
\text { to perceived barriers to } \\
\text { exploration of emotional } \\
\text { concerns, including spiritual } \\
\text { issues, and the discussion } \\
\text { of prognosis and dying, } \\
\text { the perception of patients' } \\
\text { responses/coping styles, and } \\
\text { the GP's personal experience } \\
\text { of the care (usually } \\
\text { expressed in terms of } \\
\text { identification with patient). }\end{array}$ & $\begin{array}{l}\text { The findings indicate the significant } \\
\text { challenges facing clinicians in discussions } \\
\text { with patients and families about death, } \\
\text { to exploring the patient's emotional } \\
\text { responses to terminal illness and spiritual } \\
\text { concerns for the patient and family. These } \\
\text { qualitative date indicate important tasks } \\
\text { in the training and clinical support for } \\
\text { doctors providing palliative care }\end{array}$ & BVS \\
\hline 8 & $\begin{array}{l}\text { Jennifer } \\
\text { Angelo \& } \\
\text { Linda Wilson, } \\
2013\end{array}$ & $\begin{array}{l}\text { Exploring } \\
\text { Occupation } \\
\text { Roles of } \\
\text { Hospice } \\
\text { Family } \\
\text { Caregivers } \\
\text { from Māori, } \\
\text { Chinese } \\
\text { and Tongan } \\
\text { Ethnic } \\
\text { Backgrounds } \\
\text { Living in } \\
\text { New Zealand }\end{array}$ & $\begin{array}{l}\text { Occupatio- } \\
\text { nal Therapy } \\
\text { Internatio- } \\
\text { nal }\end{array}$ & $\begin{array}{l}\text { The purpose of this study was to explore palliative } \\
\text { caregiver occupations among Māori, Chinese and } \\
\text { Tongan ethnicities. Six informants participated, } \\
\text { one woman and one man fromeach ethnic group. } \\
\text { In each of their homes, informants were asked } \\
\text { to discuss what it was like caring for their dying } \\
\text { family member. }\end{array}$ & $\begin{array}{l}\text { The occupational themes } \\
\text { resulting from these } \\
\text { interviews were food } \\
\text { preparation, spirituality and } \\
\text { family gathering. Therapists } \\
\text { need to be aware of the } \\
\text { differences in how people } \\
\text { care for family members } \\
\text { within their ethnicity. }\end{array}$ & $\begin{array}{l}\text { Implications are that occupational therapists } \\
\text { can help families identify activities } \\
\text { important to them within the main } \\
\text { occupational themes: different types of } \\
\text { foods and their preparations, various ways } \\
\text { to express spirituality and how families } \\
\text { gather together members of their extended } \\
\text { family. Further, clinicians need to take on } \\
\text { the role of a "not-knowing" but curious } \\
\text { health-care provider in order to meet the } \\
\text { needs of caregivers. The limitation was the } \\
\text { small number of participants who all lived in } \\
\text { one geographic area. Future studies should } \\
\text { include a wider group of ethnicities. }\end{array}$ & $\begin{array}{l}\text { PUBMED/ } \\
\text { SCOPUS }\end{array}$ \\
\hline
\end{tabular}




\begin{tabular}{|c|c|c|c|c|c|c|}
\hline $\mathbf{N}$ & $\begin{array}{c}\text { Authors } \\
\text { and } \\
\text { Year }\end{array}$ & Title & Journal & Sample & Main findings & Conclusion \\
\hline 9 & $\begin{array}{l}\text { Michiyo } \\
\text { Ando Akira } \\
\text { Tsuda } \\
\text { Tatsuya } \\
\text { Morita } 2007\end{array}$ & $\begin{array}{l}\text { Life review } \\
\text { interviews } \\
\text { on the } \\
\text { spiritual } \\
\text { well- } \\
\text { being of } \\
\text { terminally } \\
\text { ill cancer } \\
\text { patients }\end{array}$ & $\begin{array}{l}\text { Support } \\
\text { Care } \\
\text { Cancer }\end{array}$ & $\begin{array}{l}\text { Structured life review interviews were } \\
\text { conducted with } 12 \text { patients in a palliative } \\
\text { care unit in Japan. They completed the } \\
\text { SELT-M (Skalen zur Erfassung von Lebens } \\
\text { qualitat bei Tumorkranken-Modified } \\
\text { Version) questionnaire before and } \\
\text { after the interviews. The patients were } \\
\text { classified into two groups: effective } \\
\text { (patients who showed an increase in the } \\
\text { SELT-M scores after the intervention) and } \\
\text { noneffective groups. Meaningful spoken } \\
\text { sentences from the patients' life reviews } \\
\text { were transcribed and correspondence } \\
\text { analysis was conducted on the sentences } \\
\text { using text mining software. }\end{array}$ & $\begin{array}{l}\text { The mean overall QOL score and spirituality } \\
\text { subscale score of the SELT-M significantly } \\
\text { increased after the life reviews from } \\
2.57 \pm 0.61 \text { to } 3.58 \pm 1.0(P=0.013) \text { and } \\
2.57 \pm 0.61 \text { to } 3.14 \pm 2.25(P=0.023) \text {, } \\
\text { respectively. Three dimensions were } \\
\text { extracted from the effective group based } \\
\text { on the scores "Positive view of life," } \\
\text { "Pleasure in daily activities and good human } \\
\text { relationships," and "Balanced evaluation } \\
\text { of life." Similarly, three dimensions were } \\
\text { extracted from the noneffective group: } \\
\text { "Worries about future caused by disease," } \\
\text { "Conflicts in family relationship problems," } \\
\text { and "Confrontation of practical problems." }\end{array}$ & $\begin{array}{l}\text { Life review interviews may be } \\
\text { effective in improving the spiritual } \\
\text { well-being of terminally ill cancer } \\
\text { patients. The potential predictors of } \\
\text { treatment success are "positive view } \\
\text { of life," "pleasure in daily activities } \\
\text { and good human relationships," and } \\
\text { a "balanced evaluation of life," while } \\
\text { those of treatment failure are "worries } \\
\text { about future caused by disease," } \\
\text { "conflicts in family relationships," and } \\
\text { "confrontation of practical problems." } \\
\text { Further intervention trials on patients } \\
\text { with predictors of treatment success are } \\
\text { promising. }\end{array}$ \\
\hline 10 & $\begin{array}{l}\text { Gudlaug } \\
\text { Helga As- } \\
\text { geirsdottir \& } \\
\text { Einar Sigur- } \\
\text { björnsson } \\
\text { \& Rannveig } \\
\text { Traustadottir } \\
\text { \& Valgerdur } \\
\text { Sigurdardot- } \\
\text { tir \& Sigridur } \\
\text { Gunnarsdot- } \\
\text { tir \& Ewan } \\
\text { Kelly } 2013\end{array}$ & $\begin{array}{l}\text { "To Cherish } \\
\text { Each Day as } \\
\text { it Comes": } \\
\text { a qualitative } \\
\text { study of } \\
\text { spirituality } \\
\text { among } \\
\text { persons } \\
\text { receiving } \\
\text { palliative } \\
\text { care }\end{array}$ & $\begin{array}{l}\text { Support } \\
\text { Care } \\
\text { Cancer }\end{array}$ & $\begin{array}{l}\text { Qualitative interviews were conducted } \\
\text { with ten persons receiving palliative care } \\
\text { from Palliative Care Services in Iceland. } \\
\text { The interviews were tape-recorded, } \\
\text { transcribed and analysed. The study } \\
\text { is in the field of practical theology } \\
\text { and used the theoretical approach of } \\
\text { hermeneutical phenomenology. }\end{array}$ & $\begin{array}{l}\text { Thematic analysis found that the spiritual } \\
\text { dimension was of significance for the } \\
\text { participants who understood it as a vital } \\
\text { element connected to seeking meaning, } \\
\text { purpose and transcendence in life. Religious } \\
\text { and non-religious aspects of spirituality } \\
\text { were expressed including strong spiritual } \\
\text { components of family relationships, the } \\
\text { meaning of God/a higher being and } \\
\text { spiritual practices which served as a key } \\
\text { factor in giving strength, activating inner } \\
\text { resources and motivating hope. Nine of the } \\
\text { participants expressed their spirituality as } \\
\text { faith. }\end{array}$ & $\begin{array}{l}\text { Spirituality was experienced broadly } \\
\text { as an important dimension of how } \\
\text { participants lived with terminal } \\
\text { illness. Religious and non-religious } \\
\text { characteristics were recognized } \\
\text { which reveals the complex nature } \\
\text { of the phenomenon. Faith was a } \\
\text { significant part of the participants' } \\
\text { spirituality indicating the importance } \\
\text { of attending to this aspect of palliative } \\
\text { care. The study suggests the potential } \\
\text { contributions of theological approaches } \\
\text { which are relevant for palliative care } \\
\text { research and practice. }\end{array}$ \\
\hline
\end{tabular}

Ando Akira inte

Tatsuya spiritual

terminally

ill cancer

patients

Helga As- Each Day as Care

geirsdottir \& it Comes": Cance

Einar Sigur- a qualitative

\& Valgerdur persons

\& Ewan

faith. 


\begin{tabular}{|c|c|c|c|c|c|c|c|}
\hline $\mathbf{N}$ & $\begin{array}{l}\text { Authors } \\
\text { and } \\
\text { Year }\end{array}$ & Title & Journal & Sample & Main findings & Conclusion & Database \\
\hline 11 & $\begin{array}{l}\text { Randy S. He- } \\
\text { bert, Richard } \\
\text { Schulz, Valire } \\
\text { C. Copeland, } \\
\text { and Robert } \\
\text { M. Arnold; } \\
2009\end{array}$ & $\begin{array}{l}\text { Preparing } \\
\text { Family } \\
\text { Caregivers for } \\
\text { Death and } \\
\text { Bereavement. } \\
\text { Insights from } \\
\text { Caregivers of } \\
\text { Terminally III } \\
\text { Patients }\end{array}$ & $\begin{array}{l}\text { Journal of } \\
\text { Pain and } \\
\text { Symptom } \\
\text { Manage- } \\
\text { ment }\end{array}$ & $\begin{array}{l}\text { Focus groups and } \\
\text { ethnographic interviews } \\
\text { were conducted with } \\
33 \text { family caregivers } \\
\text { (bereaved or current) of } \\
\text { terminally ill patients. The } \\
\text { interviews were audiotaped, } \\
\text { transcribed, and analyzed } \\
\text { using the constant } \\
\text { comparative method. }\end{array}$ & $\begin{array}{l}\text { Life experiences such as the duration of caregiving/ } \\
\text { illness, advance care planning, previous experiences } \\
\text { with caregiving or death, and medical sophistication } \\
\text { all impacted preparedness, or the degree to which } \\
\text { a caregiver is ready for the death and bereavement. } \\
\text { Regardless of life experiences, however, all caregivers } \\
\text { reported medical, practical, psychosocial, and } \\
\text { religious/spiritual uncertainty. Because uncertainty } \\
\text { was multidimensional, caregivers often needed more } \\
\text { than prognostic information in order to prepare. } \\
\text { Communication was the primary mechanism used } \\
\text { to manage uncertainty. Good communication } \\
\text { included clear, reliable information, combined with } \\
\text { relationship-centered care from health care providers. } \\
\text { Finally, preparedness had cognitive, affective, and } \\
\text { behavioral dimensions. }\end{array}$ & $\begin{array}{l}\text { To prepare, some caregivers } \\
\text { needed information tailored } \\
\text { to their uncertainty (cognitive), } \\
\text { others needed to "mentally" or } \\
\text { "'emotionally" prepare (affective), } \\
\text { and still others had important tasks } \\
\text { to complete (behavioral). In order to } \\
\text { better prepare family caregivers for } \\
\text { the death of a loved one, health care } \\
\text { providers must develop a trusting } \\
\text { relationship with caregivers, provide } \\
\text { them with reliable information } \\
\text { tailored to their uncertainty, and } \\
\text { allow time for caregivers to process } \\
\text { the information and complete } \\
\text { important tasks. }\end{array}$ & SCOPUS \\
\hline 12 & $\begin{array}{l}\text { Bianca } \\
\text { Sakamoto } \\
\text { Ribeiro } \\
\text { Paiva \& } \\
\text { André Lopes } \\
\text { Carvalho \& } \\
\text { Giancarlo } \\
\text { Lucchetti } \\
\text { \& Eliane } \\
\text { Marçon } \\
\text { Barroso } \\
\text { \& Carlos } \\
\text { Eduardo } \\
\text { Paiva; } 2015\end{array}$ & $\begin{array}{l}\text { "Oh, yeah, } \\
\text { I'm getting } \\
\text { closer to god": } \\
\text { spirituality and } \\
\text { religiousness } \\
\text { of family } \\
\text { caregivers of } \\
\text { cancer patients } \\
\text { undergoing } \\
\text { palliative care }\end{array}$ & $\begin{array}{l}\text { Support } \\
\text { Care } \\
\text { Cancer }\end{array}$ & $\begin{array}{l}\text { This study was an } \\
\text { exploratory and descriptive } \\
\text { qualitative study. The } \\
\text { qualitative approach to the } \\
\text { data was based on Bardin's } \\
\text { content analysis technique. } \\
\text { The consolidated criteria } \\
\text { for reporting qualitative } \\
\text { research (COREQ-32) was } \\
\text { used in the description of } \\
\text { the results. Thirty FCs of } \\
\text { individuals with advanced } \\
\text { cancer undergoing palliative } \\
\text { care were included. }\end{array}$ & $\begin{array}{l}\text { Analysis of the FCs' narratives indicated that the FCs } \\
\text { considered that religiousness and faith in God or a } \\
\text { Supreme Being provide them with the strength to } \\
\text { cope with the suffering associated with the care of } \\
\text { relatives with advanced cancer. Many FCs emphasized } \\
\text { that talking about God was somehow comforting } \\
\text { and made them feel at peace with themselves. Four } \\
\text { categories were identified in the FCs' narratives: } \\
\text { (1) increase in faith and closeness to God becomes } \\
\text { stronger, (2) rethink life issues, (3) negative } \\
\text { interference in the extrinsic religiosity, and (4) quest } \\
\text { for religiousness to gain strength or support. A } \\
\text { conceptual framework was developed. }\end{array}$ & $\begin{array}{l}\text { The results of the present study } \\
\text { indicated that S/R are a coping } \\
\text { strategy frequently used by FCs of } \\
\text { individuals with advanced cancer. The } \\
\text { perceptions of the FCs interviewed } \\
\text { in the present study corresponded to } \\
\text { the four distinct categories related to } \\
\text { spirituality and religiousness. }\end{array}$ & SCOPUS \\
\hline
\end{tabular}




\section{Author \\ N and}

Year

13 Leslie P.

Scheu-

nemann;

Journa

Thomas V. Critically III

Cunningham; Patients'

Robert M. Preferen-

Arnold; ces and

Praewpanna- Values

rai Buddad- With

humaruk; Surroga-

Douglas B. tes: An

White; 2015 Empirical

Analysis*

14 Kirsten

Wentlandt,

Debika Bur-

man, Nadia

Swami, Sarah tients with

Hales, Anne advanced

Rydall, Gary cancer

Rodin, and as-

Christopher sociation

Lo and with com-

Camilla munica-

Zimmermann; tion with

2012 professio-

nal caregi-

vers
Critical Fifty-four physicians and 159 surrogates for

Care

71 patients. We audio-recorded 71 confe-

rences in which clinicians and surrogates

discussed life-sustaining treatment decisions for an incapacitated patient near the end of life. Two coders independently coded each instance in which clinicians or surrogates discussed the patient's previously expressed treatment preferences or values. They subcoded for values that are commonly important to patients near the end of life. They also coded treatment recommendations by clinicians that incorporated the patient's preferences or values.

Psycho- Patients with advanced cancer but with Oncolo- good performance status were recruited gy from 24 medical oncology clinics, to participate in a cluster-randomised controlled trial of early palliative care intervention. Measures included the Quality of Life at the End of Life preparation for EOL subscale, and measures of CPC, functional status, comorbidity, spiritual well-being and symptom severity. Using chi-squared tests, t-tests and multivariate regression analyses, we examined the variables associated with preparation for EOL. We also examined the frequency distributions of individual EOL preparation items and used logistic regression to examine their associations with adequacy of CPC.
In $30 \%$ of conferences, there was no discussion

about the patient's previously expressed preferences or values. In $37 \%$, clinicians and surrogates discussed both the patient's treatment preferences and values. In the remaining 33\%, clinicians and surrogates discussed either the patient's treatment preferences or values, but not both.

In more than $88 \%$ of conferences, there was no conversation about the patient's values regarding autonomy and independence, emotional wellbeing and relationships, physical function, cognitive function, or spirituality. On average, 3.8\% (sd, 4.3; range, 0-16\%) of words spoken pertained to patient preferences or values.

In the 469 patients, characteristics associated with better EOL preparation were better CPC, older age, living alone, less symptom burden and better spiritual well-being. Thirty-one per cent agreed that they worried 'quite a bit' or 'completely' about their family's preparation to cope with the future, and $27 \%$ agreed that they would be a burden to their family. All preparation items except regrets about life were associated with adequacy of communication.
Conclusion

Database

In roughly a third of ICU family

SCOPUS risk of death, neither clinicians nor surrogates discussed patients preferences or values about endof-life decision making. In less than $12 \%$ of conferences did participants address values of high importance to most patients, such as cognitive and physical function. Interventions are needed to ensure patients' values and preferences are elicited and integrated into end-of-life decisions in ICUs.

A substantial minority of patients with advanced cancer but with good performance status are concerned about EOL preparation, particularly in relation to thei families. Better CPC may help patients prepare not only practically but also personally and socially in relation to the dying process and the welfare of their families. 
It is common and even considered normal, to prioritize the critical patient care in detrainment of the caregivers, but there is a need to change this usual behavior and maintain the family members as an extension of the care given to patients. According to Loiselle and Sterling (2011) [4] the relief of pain cannot suppress the necessity of attention to how the process of death affects physical, functional, psychosocial and spiritual needs of all stakeholders involved.

One of the main characteristic of palliative care is the spiritual caregiving; $67 \%$ of people die in hospitals or long-term care facilities without assured access to spiritual care in the USA [5]. Spirituality is a multidimensional state that envelops meaning of life questions; it's a step to deal with your own mortality, linked with religious and non-religious traces. Spiritual wellbeing is a complement to all health strands, united with physical and psychosocial status. It is necessary to put spiritual guidance into the routine of practicing medicine, ANGELO and WILSON (2013) [6] suggests the facilitation of activities with patients and families with bible readings, providing conditions to go outside to gardens to energizing therapies, energy conservation techniques; all that increases family ties, listening to their needs and helping to find solutions to facilitate basic life activities autonomy.

ANDo et al. (2007) [7] conducted life review interviews with palliative care patients, helping them to (1) review both good and bad memories and reevaluate these memories, (2) pay attention to, not only the negative aspects and positive aspects of their life, (3) refind hobbies or interests in the reminiscence that relate with their comfort, and (4) remember good relationships with others or form new relationships. The answers for the ones with improved spiritual wellbeing were 'positive view of life', 'pleasure in daily activities and good human relationships' and balanced evaluation of life'; the ones whose cores did not improve had the dimensions including 'worries about future caused by disease', 'conflicts in family relationships' and 'confrontation of practical problems'.

In a study conducted by AsgeIRSDOtTIR et al. (2013) [3] the patients at end of life care experienced characteristics of existential and spiritual distress and the majority expressed how their situation influenced their loved ones, being aware of the impact of the illness on the family members even to the extent that they were considered to suffer more than they themselves, picturing the family as a non-religious spiritual resource in the caring process which draws attention to the importance of attending to the spiritual needs of the family as a whole.

Considering DaALEMAN et al. (2008) [5] writings clinicians and other health care workers consider spiritual care at the end of life as a series of highly fluid interpersonal processes in the context of mutually recognized human values and experiences, rather than a set of prescribed and proscribed roles. To WentLANDT et al. (2012) [8] patients worries about their family's ability to cope, fears of death and dying; and anxiety about becoming a burden, undermining their sense of well-being and dignity.

All caregivers share similar concerns, going from how to prepare meals to maintain the family structure and being full-time present. At HEBERTH et al. (2009) [9] study all caregivers have reported medical, practical, psychosocial, and religious/spiritual uncertainty; many are not prepared for death and can experience psychological morbidity. The care of individuals with severe chronic diseases imposes a heavy physical and emotional load on family caregiver's inasmuch they combine their usual activities with the ones related to caregiving, commonly resulting in absence from their professional, family, and social life.

Being necessary to improve communication about issues (medical, psychosocial and spiritual) that encircle death and dying will lead to caregivers being better prepared for the death and, as a result, improve their well-being. MichieLs et al. (2009) [10] points out the value of involving patients' relatives 
in the information process, but also respecting the patient autonomy obtaining their consent before disclosing information to their relatives. Any intervention must be congruent with the patients' values and preferences -according to the principles of autonomy, substituted judgment and bests interests, integrated in end of life decisions in intensive/special care units and examining the impact of those efforts in the patient and family [11].

Ciemmens et al. (2015) [12] brings out that at the end of life or during times of serious illness, patients and families identified behaviors of presence, reassurance, and honoring choices as important. According to patients/families, health care providers must be compassionate and empathetic and possess skills in listening, connecting, and interacting with patients and families.

Michiels and Colleagues (2009) [10] research shows that clinical specialists and general practitioners discuss most end-of-life topics with the patient, but omit important issues such as end-of-life hastening options and life expectancy. The lack of information may influence patients' treatment preferences, favoring life-extending therapy over comfort care, increasing anxiety, depression or dissatisfaction. The reasons for this lack of information might be dual, with some patients actively avoiding finding out overly detailed information, reflecting the tension between wanting information, but not wanting bad news and with physicians providing incorrect information or none at all.

In order to expect the patients to tell their fears, clinicians must have a 'preparation dialogue' [8] with end-of-life patients and their relatives may be used to probe specific patient concerns and help patients to prepare practically, personally and socially in relation to dying process and the welfare of their families. Kelly et al. (2008) [13] findings indicate the significant challenges facing clinicians in discussions with patients and families about death, to exploring the patient's emotional responses to terminal illness and spiritual concerns for the patient and family, its qualitative research indicates important tasks in the training and clinical support for doctors providing palliative care.

\section{Conclusion}

Our review concludes that it is necessary to include the family into the routine of end of life care; studies show that the holistic view of the patients involves their family wellbeing. They must have spiritual guidance, psychological and social help, and also a good and open communication with the health professionals.

To this sensitive approach clinicians shall have information on how to deal with this situation, not only in intensive care units and hospices, but also all the levels of assistance. We suggest that further studies should focus on developing activities that help improve the involvement of families, patients and the health team, and to prove at a multi central research how caring for the family members/care givers at end of life care impacts at the patients.

\section{References}

1. World Health Organization (2002). National cancer control programmes: policies and managerial guidelines. WHO, Geneva, p 84

2. Schneider M., Steele R., Cadell S., Hemsworth D. Differences on psychosocial outcomes between male and female caregivers of children with life-limiting illnesses. J Pediatr Nurs, (2011), 26 (3): 186-199.

3. Asgeirsdottir GH, Sigurbjörnsson E, Traustadottir R, Sigurdardottir V, Gunnarsdottir S, Kelly E. "To Cherish Each Day as it Comes": A qualitative study of spirituality among persons receiving palliative care. Supportive Care Cancer 2013; 21(5):1445-1451.

4. Loiselle CG, Sterling MM. Views on death and dying among health care workers in an Indian cancer care hospice: Balancing individual and collective perspectives. Palliative Med 2012; 26(3):250-256.

5. Daaleman TP, Usher BM, Williams SW, Rawlings J, Hanson LC. An exploratory study of spiritual care at the end of life. Ann Fam Med 2008; 6(5):406-411. 
6. Angelo J, Wilson L. Exploring occupation roles of hospice family caregivers from māori, chinese and tongan ethnic backgrounds living in New Zealand. Occup Ther Int 2014; 21(2):81-90.

7. Ando M, Tsuda A, Morita T. Life review interviews on the spiritual well-being of terminally ill cancer patients. Supportive Care Cancer 2007; 15(2):225-231.

8. Wentlandt K, Burman D, Swami N, Hales S, Rydall A, Rodin G, et al. Preparation for the end of life in patients with advanced cancer and association with communication with professional caregivers. Psycho-Oncology 2012; 21(8):868-876.

9. Hebert RS, Schulz R, Copeland VC, Arnold RM. Preparing Family Caregivers for Death and Bereavement. Insights from Caregivers of Terminally III Patients. J Pain Symptom Manage 2009; 37(1):312.

10. Michiels E, Deschepper R, Bilsen J, Mortier F, Deliens L. Information disclosure to terminally ill patients and their relatives: Self-reported practice of Belgian clinical specialists and general practitioners. Palliative Med 2009; 23(4):345-353.

11. Scheunemann LP, Cunningham TV, Arnold RM, Buddadhumaruk P, White DB. How clinicians discuss critically ill patients' preferences and values with surrogates: An empirical analysis. Crit Care Med 2015; 43(4):757-764.

12. Ciemins E. L., Brant J., Kersten D., Mullette E., and Dickerson D.. Journal of Palliative Medicine. 2015, 18(3):282-285.

13. Kelly B., Varghese F. T., Burnetta P., Turnera J., Robertson M., Kelly P., Mitchell G. and Treston P..General practitioners' experiences of the psychological aspects in the care of a dying patient. Palliative and Supportive Care 2008; 6(02):125-131.

14. Bingen K., Kupst M. J., and Himelstein B. Journal of Palliative Medicine. 2011, 14(9):1009-1016.

15. Paiva BSR, Carvalho AL, Lucchetti G, Barroso EM, Paiva CE. "Oh, yeah, I'm getting closer to god": spirituality and religiousness of family caregivers of cancer patients undergoing palliative care. Supportive Care Cancer 2015; 23(8):2383-2389.
Publish in International Archives of Medicine

International Archives of Medicine is an open access journal publishing articles encompassing all aspects of medical science and clinical practice. IAM is considered a megajournal with independent sections on all areas of medicine. IAM is a really international journal with authors and board members from all around the world. The journal is widely indexed and classified Q1 in category Medicine. 